\title{
IMPLEMENTATION OF NATIONAL-REGIONAL COMPONENT IN THE EDUCATIONAL PROCESS IN THE REPUBLIC OF UZBEKISTAN
}

\section{Nodir Takhirovich Suyarov}

Teacher, Namangan State University, Namangan, Uzbekistan

\author{
Elmirza Temirovich Erkaev
}

Candidate Of Pedagogical Sciences, University Of Public Security Of The Republic Of Uzbekistan

\section{ABSTRACT}

This article discusses the possibility of national-regional component in art education students, provides a detailed analysis and the use of creative experience in the heritage of their ancestors of educational and educational activities of students, taking into account the features of cultural and historical traditions of the people.

KEYWORDS: - Regional component, the national regional traditions, artistic traditions, national clothes.

\section{INTRODUCTION}

It is known that more than one hundred and thirty peoples live in Uzbekistan, each of which has unique characteristics of material, spiritual, national and artistic culture. The overwhelming majority of these peoples have developed over the centuries as ethnic communities on the territory of Uzbekistan, and in this sense they are indigenous peoples who have played a historical role in the formation of the Uzbek statehood. Thanks to the unifying role of the Uzbek people on the territory of Uzbekistan, a unique unity and diversity, spiritual community and union of different peoples have been preserved. Within the framework of the national-regional component, it is necessary to ensure the preservation and development of traditional forms of management, the augmentation of spiritual values created by art and literature, folk art, the development and expansion of the scope of application of national cultural and historical ethno-pedagogical traditions in the educational and upbringing activities of students and youth.

The Uzbek people should be proud of their fine, applied and architectural arts. Because on the 
CURRENT RESEARCH JOURNAL OF PEDAGOGICS 2(8): 117-121, August

2021 DOI: https://doi.org/10.37547/pedagogics-crjp-02-08-25

ISSN 2767-3278

(C)2021 Master Journals

Crossref do) 81 Google

Accepted $26^{\text {th }}$ August, 2021 \& Published 31 th August, 2021

territory of Uzbekistan were extremely developed, even before our era, such types of fine arts as painting, sculpture, architecture.

\section{THE MAIN FINDINGS AND RESULTS}

In teaching fine arts, it is necessary to take the positions of a dialectical approach to the relationship between national and international factors - traditions and historically established forms of artistic activity, and at the same time the centuries-old experience of international artistic culture.

Artistic and craft traditions are an irreplaceable school of aesthetic education. They develop diligence, perseverance, accuracy, thoroughness, i.e. these are the features that we must adopt from the pedagogical practice of the people, since they are most clearly expressed in the samples of the masters of folk applied art. This provision serves as the basis so that at this stage we can work on a more harmonious development of students in secondary schools.

Applied art of Uzbekistan occupies a special place against the richest and most diverse background of artistic creativity of the peoples of the country. It has many genres, techniques, decorative motives and forms, historically established skills, artistic traditions.

The pinnacle of folk decorative art is the national costume. It focuses on many different crafts. They are not just subordinate to each other, but serve as an expression of the essence of the people through vestments.

The Uzbek national costume, created in ancient times and used to this day, reflects the national specifics of the Uzbek people, is closely related to its culture and history.

In other words, the costume is the most striking and original determinant of national identity, in it the material principle is integrally combined with the spiritual world of the past. The costume reflects, as in a mirror, the occupations of the ancestors: farmers and pastoralists, the climate and trade routes, the ideals of beauty and religion, changing socio-economic conditions and contacts with other peoples. It has distinctions and peculiarities characteristic for each region.

The specificity of the Uzbek folk costume is determined by its belonging to folk art, which makes it an integral part of the objective world of a person, a part of his daily life and at the same time distinguishes it as an independent type of folk art according to its artistic and aesthetic characteristics.

These features are expressed in the system of existing traditional aesthetic principles that determined the people's view of beautiful clothes in general. These include the convenience of clothing, the brightness and elegance of the fabric, the cut that gives a clear silhouette, expressive decor, bright and life-affirming color, sharpening the decorative sound of the costume. Thus, deep purposefulness and beauty were combined in folk clothing. This unity allows us; to use its properties and pedagogical potential in the process of art education of aesthetic education of schoolchildren.

The specific features of the Uzbek folk costume as an object of aesthetically, cognitive and artistic activity are expressed in the peculiarities of its figurative content, which carries a deep aesthetic and educational content.

The Uzbek costume has been created for centuries. However, the national costume can be seen today only on the theatrical stage or stage venues, in concert performances of musical groups.

It includes clothing, both every day and festive, for working at home and in the field, performing rituals, visiting guests, and a mosque. The constituent elements of folk clothing depend on the natural environment: summer heat or winter 
CURRENT RESEARCH JOURNAL OF PEDAGOGICS 2(8): 117-121, August

2021 DOI: https://doi.org/10.37547/pedagogics-crjp-02-08-25

ISSN 2767-3278

(C)2021 Master Journals

\section{Crossref doi) 81 Google}

Accepted $26^{\text {th }}$ August, 2021 \& Published 31 th August, 2021

cold, as well as the way of life associated with certain economic activities. Artistic tastes and religious beliefs play an important role in the design of the costume.

In addition, in different regions and regions of residence, Uzbeks have developed their own peculiarities in clothing. In general, the Uzbek costume is based on ancient forms of Turkic clothing.

This means, it can be said, that the Uzbek national costume, developing in the general mainstream of oriental clothing, at the same time has its own distinctive, unique features and a modern chapon - the robe is not quite the same garment as it was, say, a hundred years ago. In general, the word chapon (robe) has been known in the West since the time of the Mongol invasion and even entered the lexicon of some peoples.

A common attribute of men's national dress is a sash - belbog, which is a square scarf made of cotton or silk fabric, folded at an angle. Usually men wore dark clothes, but belbog, which was tied around the waist, preferred bright colors. Particularly elegant were the belts on ceremonial clothes - velvet or embroidered, with silver patterned plates and buckles.

The traditional shirt - kuylak - was the casual men's clothing, which at first had a length below the knees, and then it was shortened to the middle of the thighs. The collar of the shirt was of two styles. In the first case, a collar was sewn to a long vertical cut. In shirts of a different style, the slit was horizontal, from shoulder to shoulder.

The inhabitants of the Tashkent and Fergana regions had a widespread men's open shirt yachtak. It was sewn from cotton fabric and was worn by both young and old. The edges of the collar were sometimes trimmed with jiyak tapes.

The costume complex also included a camisole a waistcoat in the waist.

The male costume was complemented by a headdress. The forms of hats were varied: kulokh or duppi (skullcap).

Duppi (skullcap) is a round or pointed cap with embroidered or woven patterns, the national headdress of many peoples of Central Asia.

Islam played its role in the custom of wearing a skullcap, which forbade the faithful to leave the house with their heads uncovered. The most common men's Chust skullcap from the Fergana Valley has a strict, modest and at the same time very decorative look. It is characterized by white thread embroidery of the ornament in the form of "kalampir" pepper pods on a black background, and sixteen patterned arches are arranged in a row along the edge. Without such a skullcap, no man will appear in the mosque, will not come to the funeral or wedding. The skullcap adorns everyone - both the gray hair of the sage and the braids of the bride. And a good fellow without a skullcap on the back of his head, as it were, is not a horseman. Popular rumor treats her with a friendly disposition: "The skullcap is not a burden for the dzhigit". Or: "There is no one to talk to - turn to the skullcap".

The Uzbek costume incorporates many types of decorative creativity of the people. This is weaving, and embroidery, and gold embroidery, and artistic processing of leather.

Uzbek women covered their heads with a scarf rumol. Often the headdress consisted of two scarves, one of which was thrown over the head, and the second, folded diagonally, was worn in the form of a headband. In the century before last, women wore headscarves with a hole for their faces, a small peshona rumol scarf was tied on their foreheads, and a turban in the form of a turban was wrapped over it.

On weekdays, the head was covered with a headscarf made of white muslin doka rumol, sometimes decorated with embroidery. The wealthier women wore headscarves woven with 
CURRENT RESEARCH JOURNAL OF PEDAGOGICS 2(8): 117-121, August

2021 DOI: https://doi.org/10.37547/pedagogics-crjp-02-08-25

ISSN 2767-3278

(C)2021 Master Journals

\section{Crossref dof 81 Google}

Accepted $26^{\text {th }}$ August, 2021 \& Published 31 th August, 2021

gold or silver tinsel. By the beginning of the twentieth century, skull-caps embroidered with silk or gold thread - duppi - became widespread. When leaving the house, an Uzbek woman always put a mursak or a man's robe over her head. Since the middle of the 19th century, the veil has become a traditional women's clothing.

Gold embroidery products of the peoples of Uzbekistan are available in some foreign museums. Unique examples of this art are in the collections of the State Hermitage Museum, Museum of Anthropology and Ethnography. Mukluho Maclay in St. Petersburg, the Museum of the Culture of the Peoples of the East in Moscow. But most of the gold embroidery products are kept in museums of Uzbekistan - the State Museum of Arts of Uzbekistan, the State Museum of National History of the Peoples of Uzbekistan, the Samarkand Museum of the History of Culture of the Peoples of Uzbekistan, the Bukhara Regional Museum of History and Local Lore, the Museum of Applied Arts of Uzbekistan in Tashkent.

Gold embroidery in Uzbekistan was the subject of research in the works of A. A. Semenov, B. P. Denike, B. V. Weimarn, B. P. Kornilov, V. Chepelova, V. S. Zatvornitskaya, L. I. Rempel,O. A. Sukhareva. The works of P.A.Goncharova, a handwritten version of which is kept in the State Museum of Arts of Uzbekistan, E.M.".

Many details of women's festive costume were decorated with gold embroidery patterns: peshonaband (headdress), sarandoz, rumol (headscarves or capes), kaltapushak (headdress of a married woman), kurtu (dress), zokhi-kurtu (gold-embroidered braid framing the front neckline of the dress ), kaltachu (upper women's dressing gown), duppi (skullcap), poicha zarduzi (women's harem pants), makhsi (velvet or cloth boots with soft soles), kaushi (shoes with a low back), etc.

For gold embroidery such fabrics as velvet, imported and local, silk, satin, muslin, broadcloth, wool, local semi-silk "alocha" fabric, and leather were used. The main material for gold embroidery was various types of metal threads.

The ornament of gold embroidery is predominantly of a vegetable nature, less often geometric. Its main motives were rosettes, palmettos, bushes, trees, branches, flowerpots, almonds, pomegranates, cherries, grapes. The motifs depicting birds on women's skullcaps, made according to special orders, are of exceptional character.

Certain plant motifs, such as "guli-chinni" chrysanthemum, "guli-kashkari" - Kashgar flower - testify to the borrowing of Chinese porcelain by Bukhara gold-embroiderers, which was imported to Central Asia for a long time, and was especially popular among the Bukhara elite of the XIX early XX centuries.

The starting point for the study was the theoretical substantiation of the problem of teaching the visual arts, taking into account the national-regional component in the general education school, since we consider the nationalregional component as a means of increasing the level of artistic and creative activity of students, as well as the formation of interest and introduction of students to the national culture.

The national-regional component is one of the priority areas in education and upbringing along with other basic components.

\section{Conclusion}

The main goal of developing a national-regional component in the content of the fine arts of a general education school is to revive the moral potential of an individual, his national identity, national pride, familiarization with the national traditions and culture of the small peoples of Uzbekistan. 
CURRENT RESEARCH JOURNAL OF PEDAGOGICS 2(8): 117-121, August

2021 DOI: https://doi.org/10.37547/pedagogics-crjp-02-08-25

ISSN 2767-3278

(C)2021 Master Journals

Crossref dof 81 Google

Accepted $26^{\text {th }}$ August, 2021 \& Published 31 th August, 2021

In addition, teaching fine arts, taking into account the national-regional component, will increase the level of moral and aesthetic development through the penetration and development of the national culture of the peoples of Uzbekistan, as well as form the creative abilities of students. To educate schoolchildren with the awareness that they live in a multinational, multicultural country, where every nation, every national culture is valuable in itself, unique and contributes to Russian and world culture.

\section{REFERENCES}

1. Andreev G.P. (1997) Development of the national-regional education system in the new social and pedagogical conditions: Diss. PhD. - Moscow.

2. Anichkin S.A. (1987) Aesthetic education of junior schoolchildren. - Sverdlovsk.

3. Asylkhanov E.S. (2002) Scientific and methodological substantiation of teaching the fine arts and the development of creative abilities of schoolchildren and students of art and pedagogical educational institutions of Kazakhstan: Author's abstract. Doctor of Pedagogical Sciences. - Moscow. - p. 50.

4. Badaev V.S. (2005) Formation of artistic culture of schoolchildren in the process of mastering the art of decorative painting (on the example of folk crafts in Russia): Author's abstract. Doctor of Pedagogical Sciences. - Moscow. - p. 32.

5. Bazhina I.A. (1997) Regionalization of education as a condition for the formation of technological culture among schoolchildren: Diss. PhD. -Kazan.

6. Bogolyubov N.S. (1993) Formation of creative abilities of secondary school students by means of fine arts, taking into account an individual approach: Dis .... doc. ped. sciences. - Moscow. - p. 387.

7. Bulatov S.S. Soipova M.S. Mansurov U.N. (2015) Symbols: image and content. Tashkent: Science and technology. - p. 71.

8. Egorova E. J. (2005) Formation of the foundations of ethnoculture in children of 7 years of age in the classroom of illustrating Komi folk tales: Author's abstract. Candidate of Pedagogical Sciences. - Moscow. - p. 16.

9. Kaplan N.I. (1981) Traditional art and modern art crafts of the peoples of the North, Siberia and the Far East. - Moscow. p. 118. 